\title{
Intake, digestibility and recovery of grains from feces of steers fed different oilseeds
}

\author{
Consumo, digestibilidade e recuperação de grãos nas fezes, de novilhos alimentados com \\ diferentes grãos de oleaginosas
}

\author{
${ }^{1}$ OLIVEIRA, Raquel Tenório \\ https://orcid.org/0000-0003-1079-1574
}

${ }^{1}$ GOES, Rafael Henrique de Tonissi e Buschinelli de

https://orcid.org/0000-0002-4744-0367

${ }^{2}$ GANDRA, Jefferson Rodrigues

https://orcid.org/0000-0002-3287-8737

${ }^{1}$ SABEDOT, Mayara Andressa

https://orcid.org/0000-0003-2830-9280

${ }^{3}$ OSMARI, Milene Puntel

https://orcid.org/0000-0003-0750-8141

\author{
${ }^{1}$ SILVA, Nayara Gonçalves da \\ https://orcid.org/0000-0003-4195-2465
}

\author{
${ }^{1}$ ANSCHAU, Douglas Gabriel \\ https://orcid.org/0000-0002-4531-2919 \\ ${ }^{1}$ OLIVEIRA, Sullyvan Silva \\ https://orcid.org/0000-0002-3295-5499
}

${ }^{1}$ PICANÇO, Yasmin dos Santos

https://orcid.org/0000-0001-7708-1716

${ }^{1}$ Universidade Federal da Grande Dourados - UFGD, Departamento de Zootecnia, Rodovia Dourados/Itahum, Km 12 - Unidade II | Caixa Postal: 364| CEP: 79.804-970, Dourados-MS, Brasil

${ }^{2}$ A Universidade Federal do Sul e Sudeste do Pará - UNIFESSPA, Departamento em Ciência Animal, Rua Alberto Santos Dumont, s/n, Bairro: Jardim Universitário | CEP: 68557-335 | Xinguara-PA

${ }^{3}$ Universidade Federal de Santa Catarina - UFSC, Departamento de Zootecnia e Desenvolvimento Rural CCA-UFSC

*Corresponding author: rafaelgoes@ufgd.edu.br

\begin{abstract}
Oilseed grains are used as a protein and energy source, increasing the energy density of the feed. The goal of the present study was to determine the nutritional profile of canola, crambe and soybean grains recovered from feces, and to evaluate the intake and digestibility of nutrients, rumen fermentation parameters of beef cattle receiving whole grains of oilseeds. Three steers, $350 \pm 23.5 \mathrm{~kg}$ body weight were distributed in a not contemporary, $3 \times 3$ double Latin square, and fed oilseed grains. Inclusion of crambe grain reduced dry matter intake by $21.02 \%$, with a higher digestibility coefficient for EE and NDF. The crude protein content of canola and crambe grains recovered were similar, but the EE content was higher for the crambe grain $(26.46 \%)$. Soybean showed the lowest values of chemical composition for grains recovered from feces. The highest dry matter intake ( $7.86 \mathrm{~kg} /$ day $)$, and the lowest NDF digestibility $(0.203 \mathrm{~g} / \mathrm{kg})$, were found for animals fed soybean. The inclusion of crambe grains reduced the rumen ammonia content $(10.97 \mathrm{mg} / \mathrm{dL})$; however, the ruminal $\mathrm{pH}$ was not altered by the inclusion of grains in the diet. Canola and soybean grains can be included in the cattle diet without altering dry matter intake;
\end{abstract}


while the inclusion of crambe grains reduces the dry matter intake and the ruminal ammonia content of the animals. Crambe grain showed the highest recovery of dry matter and ether extract from feces.

Key Words: Canola, Crambe, Digestibility, Recovery, Soybean.

\section{RESUMO}

Para se avaliar a inclusão de grãos inteiros das culturas de canola, crambe e soja na dieta de bovinos em confinamento, sobre o consumo, digestibilidade, parâmetros ruminais e recuperação dos grãos nas fezes, delineou-se um ensaio estatístico em quadrado latino com três dietas e três bovinos providos de cânula ruminal. Os resultados constataram que a inclusão do grão de crambe reduziu o consumo de matéria seca em $21,02 \%$, e proporcionou aumento na digestibilidade do extrato etéreo e fibra em detergente neutra. O percentual de extrato etéreo recuperado nas fezes foi de $44,15 \%$ para grão de canola e $61,53 \%$ para o grão de crambe. Encontrou-se menor digestibilidade da fibra em detergente neutra para dietas contendo grão de soja $0,203 \mathrm{~g} / \mathrm{kg}$, embora seu consumo aumentou em relação ao crambe $7,86 \mathrm{~kg} /$ dia. A inclusão de crambe apresentou redução nos teores de amônia ruminal $\left(\mathrm{N}_{-} \mathrm{NH}_{3}\right)$, com valores médios de $10,97 \mathrm{mg} / \mathrm{dL}$. Portanto, o grão de crambe pode ser incluído na dieta de bovinos de corte em $14 \%$ da MS, sendo uma alternativa em potencial como grão de oleaginosa na alimentação de ruminantes. Assim como, os grãos de canola e soja sem afetar a digestibilidade da matéria seca e da proteína bruta, contudo, devem ser usados com cautela.

Palavras Chaves: Canola, Crambe, Digestibilidade, Recuperação, Soja

\section{INTRODUCTION}

Oilseed grains are used as a protein and energy source due to the high lipid content inside the seed, which is surrounded by a protein matrix, which can prevent the rapid release of lipid content in the rumen environment and reduce the negative effects on ruminal digestion of fiber (Rennó et al., 2015).

Soybean grain is very widespread, and its use is possible both in the animal feed industry and in the human industry, therefore, there is competition for its use. It is an easy source to be purchased and its by-products are used more for animal feed. Canola grain is mainly used for oil production, as it is a rich source of unsaturated fatty acids, with functional potential, however, it has a higher added value. Crambe grain is a rich source of lipids and proteins; has $35 \%$ oil, which basically consists of $90.1 \%$ unsaturated fatty acids, with $56.7 \%$ of this composition as erucic acid (Jasper et al., 2013), its main antinutritional factor, and should be added with caution in animal feed (Goes et al., 2016).

Several researches are carried out to evaluate the inclusion of oilseed grains in ruminant feeding, as a source of energy and protein for animal production, on the intake and digestibility of nutrients (Goes et al., 2011; Bassi et al., 2012; Rennó et al., 2015; Côrtes et al., 2015), however, Rennó et al., (2015) and Côrtes et al., (2015) highlighted that the chemical composition of grains recovered from feces is related to efficiency of nutrient use by animals.

The goal of this study was to determine the nutritional profile of canola, crambe and soybeans recovered from feces, as well as to evaluate nutrient intake and digestibility, ruminal fermentation 
parameters of beef cattle receiving diets with inclusion of whole oilseed grains.

\section{MATERIAL AND METHODS}

The experiment was conducted in the Ruminant Nutrition sector, Animal Nutrition Laboratory (LANA), School of Agricultural Sciences, Federal University of Grande Dourados, and in the Laboratory for the evaluation of oilseed by-products, at the Center of Research Laboratories in Agroenergy and Environmental Conservation (LAPAC/FINEP), municipality of Dourados, state of Mato Grosso do Sul. All experimental procedures were performed according to ethical standards, approved by the institutional animal experimentation committee, according to protocol 004/2013CEUA/UFGD.

Three crossbred steers, castrated, average body weight of $350 \pm 23.5 \mathrm{~kg}$, provided with a permanent ruminal cannula, were randomly distributed in two, non-contemporary $3 \times 3$ Latin square. Animals were housed in individual covered cubicles of $8 \mathrm{~m}^{2}$ $(2 \times 4 m)$, with dirt floor, containing individual feeders and drinkers.

The experimental period consisted of 90 days, divided into six periods of 15 days each, with the first 8 days of adaptation to diets and seven days for experimental collections. Diet was offered individually and mixed manually in the trough, and divided into two daily meals ( 8 am and 4 pm). The amount offered was adjusted daily, allowing a minimum of $10 \%$ surplus, throughout the experimental period.

The treatments consisted of diets based on corn silage; ground corn; inclusion of whole grains of canola, crambe or soybean; urea and mineral mixture (Table 1).

Feces were collected on the 9th, 10th and 11th days at 6-h intervals, for each period, in the amount of $300 \mathrm{~g} /$ day. Collection of feces for the separation of canola, crambe and soybean grains occurred on the 12th, 13th and 14th days of the experimental period, at 6-h intervals. Samples were washed through 4-, 2- and 1-mm sieves, as described by Rennó et al. (2015). Canola, crambe and soybean grains were collected manually with the aid of tweezers, weighed, dried in a forced ventilation oven $\left(55^{\circ}\right.$ for 72 h) and manually ground in a porcelain mortar and pistil.

Oilseed grain intake on a dry matter basis (kg/day) was calculated using the formula: DMIgr $=(\mathrm{DMI} \times \%$ grain in the diet) $/ 100$. The concentration of oilseed grains excreted in feces (DM basis) was obtained by the equation: $\mathrm{DME}=$ (grain DM intake - grain DM excretion) / total excretion of feces*100. The excretion of $\mathrm{DM}$ from the grains (kg/day) was obtained by the equation: DME = (total excretion of feces $\times \%$ soybean grain in feces) $/ 100$.

The chemical composition of the diets (Table 1), the feces and the grains recovered from feces was analyzed to determine the contents of dry matter (DM, method 967.03), mineral matter or ash (method 942.05, burning at $600{ }^{\circ} \mathrm{C}$ for $2 \mathrm{~h})$, organic matter $(\mathrm{OM}=100$-ash $)$, crude protein (CP, Nx6.25, method 981.10), ether extract (EE, method 920.29); as described by AOAC, (1990). Fractions of neutral detergent fiber (NDF), acid detergent fiber (ADF) were determined according to Van Soest et al., (1991), using $100 \mathrm{~g} / \mathrm{m}^{2}$ non-woven bags (TNT) using a fiber determiner (TE-149 - Tecnal ${ }^{\circledR}$ ). 
Table 1. Percent composition (\%) of concentrates and chemical composition of experimental diets provided to cattle.

\begin{tabular}{lccc}
\hline & \multicolumn{3}{c}{ Oilseed grains } \\
\cline { 2 - 4 } Ingredients & Canola & Crambe & Soybean \\
\hline Corn silage & 60.00 & 60.00 & 60.00 \\
Ground corn & 24.03 & 20.9 & 19.72 \\
Canola grain & 10.40 & - & - \\
Crambe grain & - & 14.10 & - \\
Soybean grain & - & - & 15.95 \\
Urea & 1.62 & 1.37 & 0.41 \\
Mineral Mix & 3.95 & 3.63 & 3.92 \\
\hline & Chemical composition $(\mathrm{g} / \mathrm{kg})$ & \\
\hline Dry matter & 528.60 & 530.10 & 520.51 \\
\hline Organic matter & 491.00 & 496.00 & 497.20 \\
Crude protein & 130.90 & 131.20 & 129.80 \\
Neutral detergent fiber & 321.10 & 385.30 & 325.60 \\
Acid detergent fiber & 167.10 & 224.80 & 172.26 \\
Ether extract & 55.10 & 86.00 & 58.90 \\
Ash & 85.90 & 82.50 & 88.10 \\
\hline
\end{tabular}

On the 15th experimental day, samples of ruminal content were collected manually immediately before feeding and 2, 4, 6, and 8 hours after the diet was supplied, at the liquid/solid interface of the ruminal environment, which were filtered through a triple layer of gauze. A sample ruminal fluid was collected to determine $\mathrm{pH}$ and ammonia nitrogen $\left(\mathrm{NH}_{3}-\mathrm{N}\right)$. Values of $\mathrm{pH}$ were measured immediately after the collection by means of a portable digital $\mathrm{pH}$ meter and for the determination of ammonia nitrogen, a $40 \mathrm{~mL}$ aliquot was separated, which was fixed with $1 \mathrm{~mL} \mathrm{H}_{2} \mathrm{SO}_{4} 1$ : 1 , stored in a glass with polyethylene lid, identified for further analysis. Determination of the levels of $\mathrm{NH}_{3}-\mathrm{N}$ was carried out according to the INCTCA N-007/1 method, described by Detmann et al., (2012).

The coefficients of total apparent digestibility of dry matter (DM), organic matter $(\mathrm{OM})$, crude protein (PB), neutral detergent fiber (NDF) and ether extract (EE), were obtained from the relationship between the total nutrients retained and the fecal excretion.

Data obtained were teste for normality of residuals and homogeneity of variances by PROC UNIVARIATE of SAS, (2014) and evaluated by PROC MIXED according to the following model:

$\mathrm{Y}_{\mathrm{ijk} \mathrm{l}}=\mu+\mathrm{A}_{\mathrm{i}}+\mathrm{P}_{\mathrm{j}}+\mathrm{C}_{\mathrm{k}}+\mathrm{D}_{\mathrm{l}}+\mathrm{e}_{\mathrm{ijkl}}$

Where: $\mathrm{Y}_{\mathrm{ijyk}}=$ dependent variable, $\mu=$ overall mean, $A_{i}=$ effect of animal $(j=1$ to 3$), \mathrm{Pj}=$ effect of period ( $\mathrm{j}=1$ to 6$), \mathrm{C}_{\mathrm{k}}$ $=$ effect of square ( $\mathrm{k}=1$ to 2$), \mathrm{D}_{\mathrm{l}}=$ effect of $\operatorname{diet}(\mathrm{l}=1$ to 3$)$ and $\mathrm{e}_{\mathrm{ijkl}}=$ experimental error. The random effect of the model was characterized by: animal (Ai) and Latin square $\left(\mathrm{C}_{\mathrm{k}}\right)$. The degrees of freedom were corrected by DDFM $=\mathrm{kr}$. Data obtained were subjected to analysis of variance. Data were tested by Tukey's test using the PROC MIXED of SAS at 
a significance of $5 \%$.

\section{RESULTS}

Intake of the diets containing crambe grain reduced $(p=0.005)$ the dry matter intake by $21.02 \%$ (Table 2), consequently, steers showed lower intake of organic matter, crude protein and NDF. However, the inclusion of crambe grains provided greater digestibility for EE and NDF.

Table 2 - Intake ( $\mathrm{kg} /$ day) and total digestibiltiy $(\mathrm{g} / \mathrm{kg})$ of nutrients of steers fed canola, crambe and soybean grains.

\begin{tabular}{|c|c|c|c|c|c|}
\hline \multirow{2}{*}{ Item } & \multicolumn{3}{|c|}{ Oilseed grains } & \multirow[t]{2}{*}{$\mathrm{SEM}^{1}$} & \multirow[t]{2}{*}{$P$-value } \\
\hline & Canola & Crambe & Soybean & & \\
\hline \multicolumn{6}{|c|}{ Intake (kg/day) } \\
\hline Dry matter & $7.85^{\mathrm{a}}$ & $6.20^{\mathrm{b}}$ & $7.86^{\mathrm{a}}$ & 0.25 & 0.005 \\
\hline Organic matter & $7.30^{\mathrm{a}}$ & $5.74^{\mathrm{b}}$ & $7.30^{\mathrm{a}}$ & 0.24 & 0.004 \\
\hline Crude protein & $1.07^{\mathrm{a}}$ & $0.84^{\mathrm{b}}$ & $1.06^{\mathrm{a}}$ & 0.09 & 0.021 \\
\hline Neutral detergent fiber & $2.89^{a}$ & $2.34^{\mathrm{b}}$ & $2.55^{\mathrm{ab}}$ & 0.18 & 0.043 \\
\hline Ether extract & 0.41 & 0.46 & 0.47 & 0.04 & 0.235 \\
\hline \multicolumn{6}{|c|}{ Digestibility $(\mathrm{g} / \mathrm{kg})$} \\
\hline Dry matter & 0.645 & 0.645 & 0.645 & 0.01 & 0.997 \\
\hline Organic matter & 0.673 & 0.669 & 0.683 & 0.01 & 0.613 \\
\hline Crude protein & 0.665 & 0.705 & 0.696 & 0.03 & 0.829 \\
\hline Neutral detergent fiber & $0.278^{\mathrm{b}}$ & $0.319^{\mathrm{a}}$ & $0.203^{c}$ & 0.01 & 0.001 \\
\hline Ether extract & $0.772^{\mathrm{c}}$ & $0.911^{\mathrm{a}}$ & $0.872^{\mathrm{b}}$ & 0.02 & 0.001 \\
\hline
\end{tabular}

${ }^{1}$ SEM: standard error of the mean

There was less ( $\mathrm{p}>0.001)$ NDF digestibility for diets containing soybean grains, although the intake of dry matter did not differ with the addition of canola ( $\mathrm{p}>0.005)$.

The chemical composition (Table 3 ) of soybean grain recovered from feces showed the lowest values for $\mathrm{EE}$
$(4.32 \%)$, crude protein $(12.91 \%)$ and ADF (14.79\%). The contents of crude protein in canola and crambe grains did not differ $(\mathrm{P}>0.005)$ from each other; however, the $\mathrm{EE}$ values for crambe grains $(26.46 \%)$ were higher $(\mathrm{P}=0.003)$ than those determined for canola grains $(16.78 \%)$. 
Table 3- Intake, Excretion and Proximate Composition of grains excreted in feces of cattle fed canola, crambe and soybean grains.

\begin{tabular}{lccccc}
\hline \multicolumn{1}{c}{ Item } & \multicolumn{3}{c}{ Oilseed grains } & \multirow{2}{*}{ SEM $^{1}$} & $P$-value \\
\cline { 1 - 4 } Intake (kg/day) & Canola & Crambe & Soybean & & \\
\cline { 2 - 4 } Excretion (kg/day) & $0.82^{\mathrm{b}}$ & $0.88^{\mathrm{b}}$ & $1.26^{\mathrm{a}}$ & 0.05 & 0.015 \\
DME (\%) & $0.12^{\mathrm{a}}$ & $0.05^{\mathrm{b}}$ & $0.05^{\mathrm{b}}$ & 0.01 & 0.002 \\
\cline { 1 - 5 } & 22.64 & 34.32 & 39.16 & 0.02 & 0.541 \\
\hline Dry matter & $94.95^{\mathrm{a}}$ & $94.86^{\mathrm{a}}$ & $91.52^{\mathrm{b}}$ & 0.63 & 0.043 \\
Organic matter & $96.91^{\mathrm{b}}$ & $97.43^{\mathrm{b}}$ & $99.73^{\mathrm{a}}$ & 0.31 & 0.001 \\
Crude protein & $29.13^{\mathrm{a}}$ & $36.51^{\mathrm{a}}$ & $12.91^{\mathrm{b}}$ & 3.12 & 0.005 \\
Neutral detergent fiber & $83.47^{\mathrm{a}}$ & $75.77^{\mathrm{b}}$ & $77.74^{\mathrm{b}}$ & 1.42 & 0.050 \\
Acid detergent fiber & $42.09^{\mathrm{a}}$ & $39.32^{\mathrm{a}}$ & $14.79^{\mathrm{b}}$ & 4.23 & 0.013 \\
Ether extract & $16.78^{\mathrm{b}}$ & $26.46^{\mathrm{a}}$ & $4.32^{\mathrm{c}}$ & 2.81 & 0.003 \\
Ash & $3.08^{\mathrm{a}}$ & $2.56^{\mathrm{a}}$ & $0.26^{\mathrm{b}}$ & 0.31 & 0.001 \\
\hline
\end{tabular}

${ }^{1}$ SEM: Standard error of the mean

The inclusion of canola, crambe or soybean grains in diets changed the ruminal $\mathrm{pH}$ and the concentration of $\mathrm{NH}_{3}-\mathrm{N}$ (Table 4). The content of $\mathrm{NH}_{3}-\mathrm{N}$ in the ruminal fluid showed a reduction with the inclusion of crambe grains, in contrast, the inclusion of canola grains resulted in high levels of $\mathrm{NH}_{3}-\mathrm{N}$ in relation to other diets.

Table 4 - Mean values of ruminal $\mathrm{pH}$ and ammonia concentration $\left(\mathrm{NH}_{3}-\mathrm{N}\right)$ of ruminal fluid from cattle fed canola, crambe and soybean grains.

\begin{tabular}{|c|c|c|c|c|c|c|c|}
\hline \multirow[t]{2}{*}{ Item } & \multicolumn{3}{|c|}{ Oilseed grains } & SEM $^{1}$ & \multicolumn{3}{|c|}{$P$-value } \\
\hline & Canola & Crambe & Soybean & & Grain & Time & Interaction \\
\hline $\mathrm{pH}$ & $6.16^{\mathrm{b}}$ & $6.72^{\mathrm{a}}$ & $6.21^{b}$ & 0.05 & 0.040 & 0.001 & 0.715 \\
\hline $\mathrm{N}-\mathrm{NH}_{3}(\mathrm{mg} / \mathrm{dL})$ & $16.05^{\mathrm{a}}$ & $10.97^{\mathrm{c}}$ & $12.99^{\mathrm{b}}$ & 0.83 & 0.001 & 0.001 & 0.109 \\
\hline
\end{tabular}

${ }^{1}$ SEM: standard error of the mean;

\section{DISCUSSION}

Crambe grains contain $90 \mathrm{~mol} / \mathrm{g}$ glucosinolates, $\quad[(\mathrm{S})-2-$ hydroxy-3butenyl glucosinolate], which causes a reduction in intake, combined with the bitter taste, providing less acceptability by animals (Canova et al., 2015; Mendonça et al., 2015). Glucosinolate reduces intake after the third day of ingestion and activity of ruminal flora in cattle after the sixth day (Goes et al.,
2016). The higher proportion of unsaturated fatty acids (AGI) in the digesta increases the secretion of cholecystokinin (CCK), which can inhibit motility in the rumen and reticulum, thus reducing food intake (Nicholson \& Omer, 1983).

Leduc et al. (2017) highlighted that the reduction in dry matter intake decreases the rate of passage through the rumen and increases nutrient digestibility, which corroborates data obtained for the 
supply of crambe grains, which caused a reduction in DM intake of the animals and showed an increase for the NDF and EE digestibility coefficients.

The digestibility for EE ( $p>0.005)$ for the inclusion of grains in the diet is in line with the chemical composition recovered from feces. Canola grain has \pm $38 \% \mathrm{EE}$ and crambe grain $\pm 43 \%$ (Goes et al., 2010, 2011), the EE content recovered from feces was $44.15 \%$ and $61.53 \%$, respectively. However, among the studied diets, the treatment that included crambe showed greater $(\mathrm{p}>$ 0.05 ) digestibility compared to the others for this component.

Fresh soybean grain has a lipid matrix surrounded by an integumented membrane protecting the grain and regulating the moisture inside the endosperm (Mateus et al., 2018). Bassi et al. (2012) supplied soybeans, cottonseed and flaxseed for Zebu steers, and found no reduction in NDF digestibility of the diets, and this result was not verified in the present study, as the inclusion of soybeans decreased $(p<0.05) \quad$ NDF digestibility. Rennó et al. (2015) tested the effects of including increasing levels of soybean grain in diets for beef cattle and high- and medium-production dairy cows and reported no differences between the levels of soybean grains in diets for NDF digestibility.

Even with a protected lipid matrix, lipids contained in soybean grain were used, since the EE content of the excreted grain was $4.32 \%$. Therefore, it is possible to observe the use of lipids without negative effects on the ruminal environment of the animals, although they were not significant. The same was not observed for canola and crambe grains, which presented mean values of $16.78 \%$ and $26.46 \% \mathrm{EE}$, that is, there was greater use, however, as these grains have a greater amount of total lipids, the recovery was greater.

According to Mizubuti et al. (2016), it has been observed a reduction in the digestibility of fiber compounds with the addition of lipid sources to the diets and the magnitude of reduction is related not only to the amount, but mainly to the type of fatty acid present in the supplement. In this sense, lipids rich in unsaturated fatty acids tend to cause greater depression in intake and digestibility, due to the toxic effect on rumen microflora, changing the permeability of the cell membrane, reducing the cell ability to regulate intracellular $\mathrm{pH}$ and nutrient uptake (Fiorentini et al., 2014).

The supply of lipid sources as whole grains results in slow release, altering the capacity of biohydrogenation, and influencing fiber digestibility, due to the negative effect that unsaturated fats available in the rumen can cause to fibrolytic bacteria (Rennó, et al., 2015; Coppock \& Wilks, 1999), The inclusion of crambe grains into the diet provided the greatest digestibility for NDF and EE.

Goes et al. (2010) highlighted that crambe grain has a high soluble fraction, while Carlson et al. (1996) highlighted low degradability $(44.5 \%$, ) due to the presence of the hull, and the digestibility can be increased by dehulling. According to Wang et al. (1999) and Goes et al (2011), canola seed has a rigid capsule that impairs degradability; Santos et al. (2004) emphasized that the presence of condensed tannin causes the protection of DM of canola grains and consequent decrease of ruminal degradability, justifying the decrease of EE digestibility of animals fed canola grains. 
Although oilseed grains are used for digestibility, the excess of nonmetabolized nutrients provides an increase in energy expenditure for animal metabolism; or even increased financial costs for animal production. The greater feeding efficiency provided by the addition of grains provides a saving in anabolism, where preformed fatty acids do not require de novo synthesis from acetate, which would prevent the caloric increase associated with this metabolic pathway, which would require a greater amount of NADPH from the pentose cycle (Sousa et al., 2009).

Lipid composition of grains recovered from feces (Table 3 ) indicates that even with the protection offered by the hull, there was use of lipids contained in the grain. Rennó et al. (2015) pointed out that the lower values for $\mathrm{EE}$ of the recovered grains compared to the ingested levels indicate the use of lipids without negative effects on the rumen environment of the animals, as can be seen for soybeans that presented values of $4.32 \%$; since the value of ether extract of fresh soybean grain is approximately $20 \%$. Canola and crambe grains also showed a reduction in EE levels, when compared to the ingested levels.

The lowest content of CP presented by grains recovered from feces results in the solubilization of the external mucilage of the seed (Cortês et al. 2015); and that the $\mathrm{CP}$ content present in this fraction is readily soluble in water. Differences in concentrations of EE and CP between the diet and in grains recovered from feces can also indicate that the integrity of the seed coat has been damaged (Doucette et al., 2001); which can justify the chemical composition values listed in Table 3.

Animals fed a diet containing crambe grain showed $(p<0.05)$ a potential of hydrogen with values close to neutrality (7.0) in relation to diets containing soybean and canola grains. Nonetheless, the test-maintained $\mathrm{pH}$ values above 5.58 , which is not only related to the good microbial growth and balance of its population, but the metabolic, systemic state and ability to catabolize and/or excrete certain metabolites as changes in the main volatile fatty acids.

According to Vargas et al. (2002), inclusion of oilseed grains in the diet positively influences rumen $\mathrm{pH}$, negatively affecting dry matter intake and rumen fermentation. Thus, the high content of ether extract for the diets provided a buffering effect, which justifies the stability observed for canola and soybean and the slight increase found with the inclusion of crambe grain. Although the values were close to what was established by Hoover (1986), with a limit of 6.2. According to Van Soest (1994), declines in rumen $\mathrm{pH}$ are responsible for the partial inhibition of fiber degradation, as they impair microbial growth and provides less accumulation of volatile fatty acids, the main factor responsible for raising the $\mathrm{pH}$.

The ruminal $\mathrm{pH}$ influences the changes that lipids undergo in the rumen, changing lipolysis and biohydrogenation at lower pH (Van Nevel \& Demeyer, 1996), resulting in escape of unsaturated fatty acids to the abomasum.

The content of rumen ammonia $\mathrm{NH}_{3}-\mathrm{N}$ (Table 4) is an important factor, since ruminal microorganisms use it as a source of nitrogen for protein synthesis (Ribeiro et al., 2001). Lipid supplementation allows a reduction in the concentration of $\mathrm{NH}_{3}-\mathrm{N}$ in the rumen fluid due to rumen defaunation (Ikwuegbu \& Sutton, 1982; Vargas et al., 
2002; Nguyen et al., 2003; Eifert et al., 2005).

The concentration of rumen $\mathrm{NH}_{3}-\mathrm{N}$ is fundamental for microbial growth and efficiency (Van Soest, 1994), so that there is no limitation in microbial fermentation, the minimum concentration of $\mathrm{NH}_{3}-\mathrm{N}$ should be around $5 \mathrm{mg} / 100 \mathrm{~mL}$ ruminal fluid

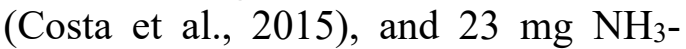
$\mathrm{N} / \mathrm{mL}$ for maximum microbial synthesis (Sampaio et al., 2009). Thus, it is highlighted that the values observed in all treatments are in accordance with the values indicated to not limit fermentation and for maximum microbial synthesis, Whole grains of oilseeds can be included in the diet for beef cattle, however the addition of crambe grain reduces the intake of dry matter, and provides greater intake of ether extract, which improves its digestibility. Chemical composition of grains recovered from feces indicates a better use of the ether extract and crude protein for the soybean grain, and the canola and crambe grains presented a similar composition when recovered from feces.

\section{ACKNOWLEDGEMENTS}

The authors would like to thank UFGD, the Coordination for the Improvement of Higher Education Personnel (CAPES) and the National Council for Scientific and Technological Development $(C N P q)$, for granting scholarships. The Foundation to support the development of education, science and technology in the state of Mato Grosso do Sul FUNDECT, for funding part of this work. Technicians Maria Gizelma de Menezes Gressler and Phaena Moraes Faria, for their assistance in conducting laboratory analyses; and the MS Foundation for Research and
Dissemination of Agricultural Technologies and Prof. Luís Carlos Ferreira de Souza, for the donation of the used grains,

\section{REFERENCES}

Association of Official Analytical Chemists (AOAC), Official Methods of Analysis, 17th ed., Arlington, VA. 1990.

Bassi, M. S.; Ladeira, M. M.; Chizzotti, M. L.; Chizzotti, F. H. M.; Oliveira, D. M. \& Neto, O. R. M. Grãos de oleaginosas na alimentação de novilhos zebuínos: consumo, digestibilidade e desempenho. Revista Brasileira de Zootecnia, v. 41, no. 2, p. 353-359. 2012.

Canova, É.B.; Bueno, M.S.; Moreira, H.L.; Possenti, R.; Brás, P. Crambe cake (Crambe abyssinica Hochst) on lamb diets. Ciência e Agrotecnologia, v.39, p. 75-81. 2015.

Carlson, K. D.; Gardner, J. C.; Anderson, V. L.; Hanzel, J. J. 'Crambe: new crop success', In: JANICK, J. (Ed.) Progress in new crops. Alexandria: ASHS Press, p. 306-322, 1996.

Coppock, C. E.; Wilks, D. L. Milk yield and composition supplemental fat in high-energy rations for lactating cows: effects on intake, digestion. Journal Animal Science, v. 69, p. 3826-3837. 1991.

Côrtes, C.; Kazama, R.; da SilvaKazama, D.; Santos, G. T.; Zeoula, L. M.; Petit, H.V.; Composition of flaxseed recovered from the faeces of dairy cows fed different proportions of whole flaxseed in the diet. Animal 
Feed Science and Technology, v. 204, p. 9-17. 2015.

Costa, N. de L.; Monteiro, A. L. G.; Silva, A. L. P. de Moraes, A.; Giostri, A. F.; Stivari, T. S. S.; Gilaverte, S.; Baldissera, T. C.; Pin A. Considerações sobre a degradação da fíbra em forragens tropicais associada com suplementos energéticos ou nitrogenados. Archivos de Zootecnia, v. 64 (R): p. 31-41. 2015.

Detmann, E.; Souza, M.; Valadares Filho, S. C.; Queiroz, A. C., Berchielli, T. T.; Saliba, E. O. S., Cabral, L. S.; Pina, D. S.; Ladeira, M. M. \& Azevedo, J. A. G., 'Métodos para análise de alimentos - INCT', Ciência Animal. Pp. 214. 2012.

Doucette, K.M., Wittenberg, K.M., McCaughey, W.P. Seed recovery and germination of reseeded species fed to cattle. Journal of Range Management. v.54, p. 575-581. 2001.

Eifert, E. C.; Lana, R. P.; Leão, M. I. Efeito da combinação de óleo de soja e monensina na dieta sobre o consumo de matéria seca e a digestão de vacas lactantes. Revista Brasileira de Zootecnia, v. 34, no.1, p. 297-308, 2005.

Fiorentini, G., Carvalho, I. P. C., Messana, J. D., Castagnino, P. S., Berndt, A., Canesin, R. C., Frighetto, R. T. S. and T. T. Berchielli. Effect of lipid sources with different fatty acid profiles on the intake, performance, and methane emissions of feedlot Nellore steers. Journal of Animal Science, v.92, p.1613-1620, 2014. doi: 10.2527/jas.2013-6868
Goes, R. H. T. B.; Souza, K. A.; Nogueira, K. A. G.; Pereira, D. F.; Oliveira, E. R.; Brabes, K. C. S. Degradabilidade ruminal da matéria seca e proteína bruta e tempo de colonização microbiana de oleaginosas, utilizadas na alimentação de ovinos. Acta Scientiarum, Animal Science, v. 33, n. 4, p. 373-378. 2011.

Goes, R. H. T. B.; Souza, K.A.; Patussi, R.A.; Cornelio, T.C.; Oliveira, E.R.; Brabes, K.C.S. Degradabilidade in situ dos grãos de crambe, girassol e soja, e de seus coprodutos em ovinos. Acta Scientiarum, Animal Science, v.32, p. 271-277. 2010.

Goes, R. H. T. B.; Yoshiraha Carneiro, M. M.; Brabes, K. C.; Lana, R. P. Coprodutos de crambe (Crambe abyssinica Hoechst) na alimentação de ruminantes. Archivos de Zootecnia, v. 65 n. 249, p. 7-16, 2016.

Hoover, W. H. Chemical factors involved in ruminal fiber digestion. Journal of Dairy Science, v. 68, n.1, p. 40-44, 1986.

Ikwuegbu, O. A.; Sutton, J. D.; 'The effect of varying the amount of linseed oil supplementation on rumen metabolism in sheep'. British Journal of Nutrition, v. 48, p.,365-375, 1982.

Jasper, S. P.; Biaggioni, M. A. M.; Silva, P. R. A. Caracterização FísicoQuímica do Óleo e do Biodiesel de Crambe Abyssinica Hochst. Nucleus, v.10, n. 2. p. 183-190, 2013.

Leduc, M.; Léroueneau-Montminy, M. P.; Gervais, R.; Chouinard, P. Y. Effect of dietary flax seed and oil on milk yield, gross composition, and fatty acid 
profile in dairy cows: A meta-analysis and meta-regression. Journal of Dairy Science, v.100, p. 8906-8927, 2017.

Mateus, R. G.; Pereira, L. C.; Jadoski, C. J.; Guilherme, D.; Alves, R. T. B. Composição químico-bromatológica de diferentes subprodutos da soja.

Pesquisa Aplicada \& Agrotecnologia, v.11, n.1, p.79-85, 2018.

Mendonça, B. P. C.; Lana, R. P.; Detmann, E.; Goes, R. H. T. B.; Castro, T. R. Torta de crambe na terminação de bovinos de corte em confinamento.

Arquivo Brasileiro de Medicina Veterinária e Zootecnia, v.67, p. 583590. 2015.

Mizubuti, I. Y.; Syperreckl, M. A.; Ribeiro, E. L. A.; Pereira, E. S.; Pinto, A. P.; Prado, O. P. P.; Peixoto, E. L. T.; Parra, A., R. P.; Massaro, F. L. J.; Guerra, G. L. Consumo, digestibilidade e balanço de nitrogênio em ovinos alimentados com rações contendo torta de Crambe. Arquivo Brasileira de Medicina Veterinária e Zootecnia, v. 68, n.3, p. 761-768. 2016.

Nguyen, T. H. N.; Nguyen, V. H.; Nguyen, T. N. Nguyen, T. T. H.; Preston, T. R.; Leng, R. A. Effect of drenching with cooking oil on performance of local yellow cattle fed rice straw and cassava foliage.

Livestock Research for Rural Development. v.15, n.7. 2003.

Nicholson, T.; Omer, S.A. The inhibitory effect of intestinal infusions of unsaturated long-chain fatty acids on forestomach motility of sheep. British Journal of Nutrition, v.50, p.141-149, 1983.
Rennó, F. P.; Cônsolo, N. R. B.; Barletta, R. V.; Ventureli, B.; Gardinal, R.; Takiya, C. S.; Gandra, J. R.; Pereira, A. S. C. Grão de soja cru e inteiro na alimentação de bovinos: Excreção de grão de soja nas fezes. Archivos de Zootecnia, v. 64, n. 248, p. 331-338. 2015.

Ribeiro, K. G.; Garcia, R.; Pereira, O. G.; Valadares Filho, S. C.; Cecon, P. R. Eficiência microbiana, fluxo de compostos nitrogenados no abomaso, amônia e $\mathrm{pH}$ ruminais, em bovinos recebendo dietas contendo feno de Capim- Tifton 85 de diferentes idades. Revista Brasileira de Zootecnia, v. 30, n. 2, p. 581-588. 2001.

Sampaio, C. B.; Detmann, E.; Lazzarini, I.; Souza, M. A.; Paulino, M.F.; Valadares Filho, S.C. Rumen dynamics of neutral detergent fiber in cattle fed low-quality tropical forage and supplemented with nitrogenous compounds. Revista Brasileira de Zootecnia, v.38, p. 560-569. 2009.

Santos, G. T.; Damasceno, J. C.; Jobim, C. C.; Gonçalves, G. D.; Neto, M. C.; Porto, P. P.; Ribeiro, C. R. Efeito dos tratamentos com autoclave e/ou ácido tânico na degradabilidade in situ e na degradabilidade in vitro de grãos de canola. Acta Scientiarum. Animal Sciences, v. 26, n. 4, p. 507-512, 2004.

Sousa, D. P.; Campos, J. M. S.; Valadares Filho, S. C.; Lana, R. P.; Sediyama, C. A. Z.; Neto, J. M. Comportamento ingestivo, consumo e digestibilidade de nutrientes, produção e composição do leite de vacas alimentadas com silagem de milho ou cana-de-açúcar com caroço de algodão. 
Revista Brasileira de Zootecnia, v.38, p. 2053-2062. 2009.

Van Nevel, C. J.; Demeyer, D. I. Influence of $\mathrm{pH}$ on lipolysis and biohydrogenation of soybean oil by rumen contents in vitro. Reproduction, Nutrition, Development, v. 36, n. 3, p.53-63, 1996.

Van Soest, P. J.; Nutritional ecology of the ruminant. 2ed. Ithaca: Cornell University Press, 476p., 1994.

Van Soest, P. J.; Robertson, J. B.; Lewis, B. A. Methods for dietary fiber,neutral detergent fiber, and nonstarch polysaccharides in relation to animal nutrition. Journal of Dairy Science, v.74, n.10, p. 3583-3597. 1991.

Vargas, L. H.; Lana, R. P.; Jham, A. N.; Santos, F. L.; Queiroz, A. C.; Mancio, A. B. Adição de Lipídios na Ração de Vacas Leiteiras: Parâmetros Fermentativos Ruminais, Produção e Composição do Leite. Revista Brasileira de Zootecnia, v. 31, n.1, p. 522-529. 2002.

Wang, Y.; Nowak, G.; Culley, D.; Hadwiger, L. A.; Fristensky, B. Constitutive expression of pea defense gene DRR206 confers resistance to blackleg (Leptosphaeria maculans) disease in transgenic canola (Brassica napus). Molecular Plant-Microbe Interaction. v. 12, p. 410-418, 1999. 